\title{
Life-long-learning: the importance of Specialist Palliative Care Teams staying informed with knowledge from other disciplines
}

It is no doubt that palliative care is an important and essential component to help improve the quality of life during the last phase of life's journey in patients being diagnosed with incurable and life-limiting diseases (1). Over the years, palliative care had been evolving from a "general" service being provided by primary care clinicians, nurses and other professionals from various disciplines to a formal "specialty" status that required inputs from specialists who had specific training and expertise in palliative medicine. Close collaboration among different stakeholders including medical oncology, radiation oncology, neurology and other healthcare disciplines are the key to ensure successful implementation of specialist palliative care especially in complex situations and for patients with severe symptom burden (2-4).

For thoroughly caring for these complex patients, specialist palliative care teams must hold sufficient knowledge about the origin, pathophysiology and trajectories of a large variety of diseases and symptoms. Moreover, they should know about the potential of different disease-modifying therapies for these patients, either in terms of symptom control or improving disease outcomes and even increasing survival (5).

This focused issue is dedicated to promoting learning from our colleagues from different disciplines, and it highlight the importance of keeping a professional eye on the developments in their fields of medicine. As advances in the primary disease disciplines are happening concurrently with advances in palliative medicine practices, refreshing the knowledge of specialist palliative care teams with the help of our colleagues will provide the best possible care for our patients.

To begin with, William Raskin (Chapter 1) first provides insights about the perception, potential and challenges of early palliative care from the view of a medical oncologist. Next, Thomas McFarlane et al. (Chapter 2) help us learn more about cutaneous toxicities of new targeted cancer therapies which are increasingly being seen in the palliative care ward and cause considerable suffering for affected patients. May Tsao et al. (Chapter 3) provide insights into the value of radiotherapy for patients with painful bone metastases and advanced stages of the disease, while Danielle N. Desautels et al (Chapter 4) report state-of-the art knowledge concerning the role of bone-modifying agents in this situation. Also, Ewelina Biskup et al. (Chapter 5) report about the often neglected potential of disease-modifying agents in the treatment of elderly patients with malignancies. They may help us overcome blind spots and substantial nihilism when such patients are referred to our specialist palliative care teams. Last but not the least, James W. Snider and Charles C Paine (Chapter 6 \& 7) report about the origin and treatment of two extremely distressing symptoms, xerostomia or sialorrhea, that often adversely impact patients quality of life.

Palliative Care has a focus on the cooperative interaction of various disciplines (6-8). With this issue, the Editors of the Annals of Palliative Medicine would like to engage in an ongoing process of sharing as much expertise as possible between all disciplines that are dedicated to deliver palliative care.

\section{Acknowledgments}

Funding: None.

\section{Footnote}

Provenance and Peer Review: This article is commissioned by the Editorial Office, Annals of Palliative Medicine for the series "Clinical Challenges and Pitfalls in Early Palliative Care: Practical Knowledge and Guidance from other Medical Specialties”. This article did not undergo external peer review.

Conflicts of Interest: All authors have completed the ICMJE uniform disclosure form (available at http://dx.doi.org/10.21037/ apm.2020.03.30). The series "Clinical Challenges and Pitfalls in Early Palliative Care: Practical Knowledge and Guidance from other Medical Specialties" was commissioned by the editorial office without any funding or sponsorship. JG, CBS II and FL served as the unpaid Guest Editors of the series. JG serves as an unpaid associate editor of Annals of Palliative Medicine from Jul 2019 to Jun 2021. CBS II serves as the unpaid Editor-in-Chief of Annals of Palliative Medicine.

Ethical Statement: The authors are accountable for all aspects of the work in ensuring that questions related to the accuracy or integrity of any part of the work are appropriately investigated and resolved.

Open Access Statement: This is an Open Access article distributed in accordance with the Creative Commons Attribution-NonCommercialNoDerivs 4.0 International License (CC BY-NC-ND 4.0), which permits the non-commercial replication and distribution of the article with the strict proviso that no changes or edits are made and the original work is properly cited (including links to both the formal publication through the relevant DOI and the license). See: https://creativecommons.org/licenses/by-nc-nd/4.0/. 


\section{References}

1. Gärtner J, Daun M, Wolf J, et al. Early palliative care: Pro, but please be precise! Oncol Res Treat 2019;42:11-8.

2. Gaertner J, Siemens W, Meerpohl JJ, et al. Effect of specialist palliative care services on quality of life in adults with advanced incurable illness in hospital, hospice, or community settings: systematic review and meta-analysis. BMJ 2017;357:j2925.

3. Oliver D. Improving patient outcomes through palliative care integration in other specialised health services: what we have learned so far and how can we improve? Ann Palliat Med 2018;7:S219-S230.

4. Parikh RB, Kirch RA, Smith TJ, et al. Early specialty palliative care--translating data in oncology into practice. N Engl J Med 2013;369:2347-51.

5. Temel JS, Greer JA, Muzikansky A, et al. Early palliative care for patients with metastatic non-small-cell lung cancer. N Engl J Med 2010;363:733-42.

6. Gaertner J, Lutz S, Chow E. Early palliative care: philosophy vs. reality. Ann Palliat Med 2015;4:87-8.

7. Simone CB 2nd. Early palliative care and integration of palliative care models in modern oncology practices. Ann Palliat Med 2015;4:84-6.

8. Ferrell BR, Temel JS, Temin S, et al. Integration of Palliative Care Into Standard Oncology Care: American Society of Clinical Oncology Clinical Practice Guideline Update. J Clin Oncol 2017;35:96-112.

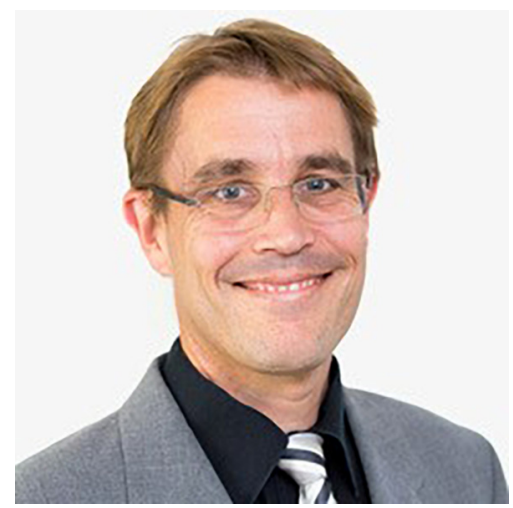

Jan Gaertner

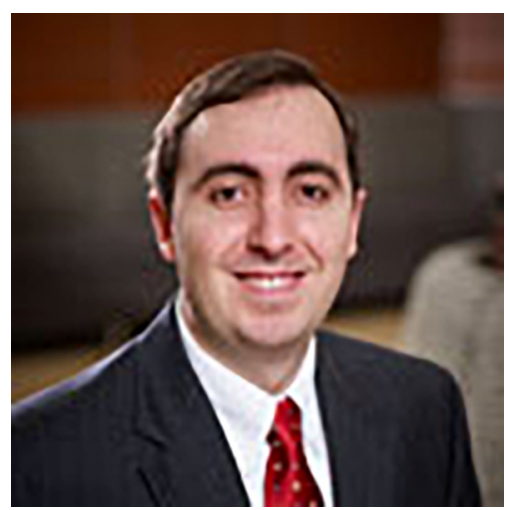

Charles B. Simone II

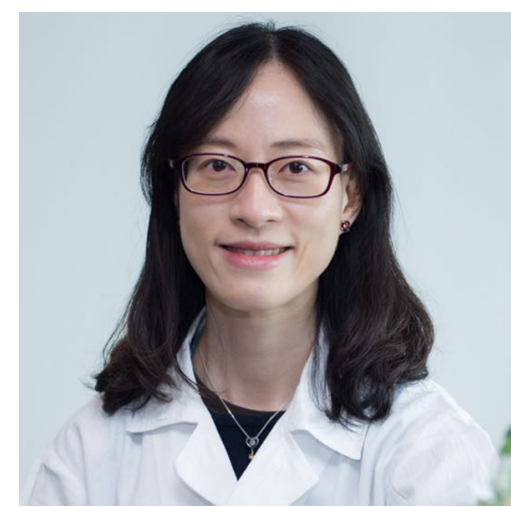

Fiona Lim

Jan Gaertner

Palliative Care Center Hildegard, Basel, Switzerland. (Email:jan.gaertner@pzbi.ch)

Charles B. Simone II

Department of Radiation Oncology, New York Proton Center, New York, NY, USA.

(Email: csimone@nyproton.com)

Fiona Lim

Department of Oncology, Princess Margaret Hospital, Hong Kong, China.

(Email: fionalimmy@gmail.com)

Submitted Feb 14, 2020. Accepted for publication Feb 27, 2020.

doi: $10.21037 / \mathrm{apm} .2020 .03 .30$

View this article at: http://dx.doi.org/10.21037/apm.2020.03.30

Cite this article as: Gaertner J, Simone CB 2nd, Lim F. Life-long-learning: the importance of Specialist Palliative Care Teams staying informed with knowledge from other disciplines. Ann Palliat Med 2020;9(3):1290-1291. doi: 10.21037/ apm.2020.03.30 